\title{
A new classification scheme of European cold-water coral habitats: implications for ecosystem-based management of the deep sea
}

\author{
Davies J.S. ${ }^{1,}{ }^{*}$, Guillaumont Brigitte ${ }^{1}$, Tempera Fernando ${ }^{2}$, Vertino A. ${ }^{3,4}$, Beuck L. ${ }^{5}$, Ólafsdóttir S.H. ${ }^{6}$, \\ Smith C. ${ }^{7}$, Fosså J.H. ${ }^{8}$, Van Den Beld Inge ${ }^{1}$, Savini A. ${ }^{3}$, Rengstorf A. ${ }^{9}$, Bayle Christophe ${ }^{1}$, \\ Bourillet Jean-Francois ${ }^{10}$, Arnaud-Haond Sophie ${ }^{1}$, Grehan A. ${ }^{9}$
}

\footnotetext{
${ }^{1}$ IFREMER, Centre de Bretagne, EEP/LEP (Laboratoire Environnement Profond), CS10070, 29280

Plouzané, France

${ }^{2}$ MARE/IMAR/DOP-UAz - Dept. of Oceanography and Fisheries/IMAR Centre, MARE - Marine and

Environmental Sciences Centre, University of the Azores, 9901-862 Horta, Azores, Portugal

${ }^{3}$ ULR CoNISMa Milano-Bicocca, Department of Earth and Environmental Sciences, University of

Milano-Bicocca, 20126 Milano, Italy

${ }^{4}$ Ghent University, Department of Geology, Renard Centre of Marine Geology, 9000 Gent, Belgium

${ }^{5}$ Senckenberg am Meer, Marine Research Department, 26382 Wilhelmshaven, Germany

${ }_{7}^{6}$ Hafrannsoknastofnunin - Marine Research Institute, Iceland

${ }^{7}$ Hellenic Centre for Marine Research, P.O. Box 2214, 71003 Heraklion, Crete, Greece

${ }^{8}$ Institute of Marine Research (IMR), Benthic Habitats and Shellfish Research Group, Nordnes 5817

Bergen, Norway

${ }^{9}$ Earth and Ocean Sciences, School of Natural Sciences, NUI Galway, Ireland

${ }^{10}$ Ifremer, Centre de Bretagne. Geosciences MarinesCS10070, 29280 Plouzané, France

*Corresponding author : J.D. Davies, email address : jaime.davies@plymouth.ac.uk
}

\begin{abstract}
:
Cold-water coral (CWC) habitats can form complex structures which provide refuge, nursery grounds and physical support for a diversity of other living organisms, but despite their ecological significance, CWCs are still vulnerable to human pressures such as fishing, pollution, ocean acidification and global warming

Providing coherent and representative conservation of vulnerable marine ecosystems including CWCs is one of the aims of the Marine Protected Areas networks being implemented across European seas and oceans under the EC Habitats Directive, the Marine Strategy Framework Directive and the OSPAR Convention. In order to adequately represent ecosystem diversity these initiatives require a standardised habitat classification that organises the variety of biological assemblages and provides consistent and functional criteria to map them across European Seas (Howell 2010). One such classification system, EUNIS, enables a broad level classification of the deep sea based on abiotic and geomorphological features. More detailed lower biotope-related levels are currently under-developed, particularly with regards deep-water habitats (>200 m depth).
\end{abstract}


This paper proposes a hierarchical CWC biotope classification scheme that could be incorporated by existing classification schemes such as EUNIS. The scheme was developed within the EU FP7 project CoralFISH to capture the variability of CWC habitats identified using a wealth of seafloor imagery datasets from across European seas and oceans. Depending on the resolution of the imagery being interpreted, this hierarchical scheme allows data to be recorded from broad CWC biotope categories down to detailed taxonomy-based levels, thereby providing a flexible yet valuable information level for management. The CWC biotope classification scheme identifies 81 biotopes and highlights the limitations of the classification framework and guidance provided by EUNIS, the EC Habitats Directive, OSPAR and FAO; with limited categories for identifying and classifying these CWC habitats. 


\section{Introduction}

\subsection{Cold-water coral habitats}

Due to the high biodiversity associated with coral-dominated habitats and their ecological significance as physical support, refuge or nursery area for other living organisms; interest in cold-water corals (CWC) has grown significantly throughout the last two decades (e.g. Freiwald et al. 2004; Bryan and Metaxas 2007; Henry and Roberts 2007; O’Hara et al. 2008, Roberts et al. 2009). Because of their vulnerability to fishing activity (Rogers, 1999; Fosså et al. 2002; Roberts 2002; Grehan et al. 2005; Waller et al. 2007), a number of CWC habitats were earmarked for conservation. In 2004, 'Lophelia pertusa reefs', 'coral gardens', 'carbonate mounds' and 'sea-pen and burrowing megafauna communities' were considered as 'threatened or declining' under the Oslo-Paris Convention for the Protection of the Northeast Atlantic (OSPAR Agreement 2004-6). In 2007, cold-water coral reefs and several types of coral gardens came under the definition of the 'Reefs' habitat listed in Habitats Directive (92/43/EEC) Annex I and in 2009, CWCs habitats were listed as Vulnerable Marine Ecosystems (VMEs) by the United Nations General Assembly (UNGA Resolution 61/105 and FAO, 2009).

CWC habitats typically occur in areas with geomorphological elevations, entirely or partly created by azooxanthellate frame-building coral species, known as CWC reefs, banks and mounds according to their size, shape and composition (e.g. Freiwald et al. 2004, Roberts et al. 2009). They are widespread along the NE Atlantic margin, at shelf breaks and on the upper continental slope (De Mol et al. 2002; Freiwald et al. 2004; Roberts et al. 2009), 


\section{ACCEPTED MANUSCRIPT}

typically found in areas of pronounced topographic relief such as the slopes of banks, submarine canyons, and seamounts (Genin et al. 1986; Frederiksen et al. 1992; MacIsaac et al. 2001; Auster et al. 2005; Davies et al. 2014, 2015) associated with hard substrate (Freiwald et al. 1999; Bryan and Metaxas 2007). Recent studies have shown the presence of cold-water coral habitats in Mediterranean deep-sea environments, occurring on the top and flanks of coral-formed or coral-topped relief (e.g. Vertino et al. 2010, Rosso et al. 2010, Savini and Corselli, 2010, Savini et al. 2014, Lo Iacono et al. 2015, Savini et al. 2016) as well as along escarpments and canyon walls (e.g. Freiwald et al 2009, Sanfilippo et al. 2012, Gori et al. 2013, Taviani et al. 2011, 2015). In order to take an ecosystem-based approach to managing deep-sea environments and achieve an ecologically-coherent network across biogeographic regions, it is essential that we develop and structure our understanding of the variety and distribution of benthic habitats or biotopes. Biotopes represent distinct biological assemblages associated with certain environmental factors such as substratum and depth (Dahl 1908).

Combining habitat maps originating from national and international programmes is necessary, but this can only be done harmoniously if standardised terminology exists. To date deep-sea maps produced by different projects / countries cannot be combined because of a lack of an agreed deep-sea classification system and recognised and agreed definitions of mapping units.

\subsection{Habitat classification schemes as a mapping prerequisite}

A premise to biotope mapping is having a systematic inventory and consistent descriptions of the biological assemblages to be used as mapping units. Habitat classification schemes are instrumental to these exercises as they present the diversity of biological units to be mapped in a structured and systematic way, ensuring consistency, repeatability and comparability between maps from different regions.

\subsubsection{The EUNIS classification}

A range of marine habitat classification schemes which are applicable to the deep sea exist, and include (i) those that are top-down schemes with a predominantly geological basis (e.g. Greene et al. 1999) and (ii) those that are hierarchical, nested, and aim at ultimately resolving biotopes, such as the European Nature Information System (EUNIS).

EUNIS is a European hierarchical habitat classification scheme that was designed to facilitate and standardise data collection and description of terrestrial, freshwater and marine 


\section{ACCEPTED MANUSCRIPT}

environments across Europe. Developing such standards in a balanced and comprehensive way throughout the diversity of environments is vital to allow continuity of data when producing habitat maps. Within the marine category (split from terrestrial environments at level 1), the deep seabed is discriminated at level 2 (A6) and subsequently divided into zones on the basis of substrate (level 3) and benthic assemblages (level 4). Topographically-based deep-sea habitat complexes such as seamounts and canyons are also included in level 3, but would be more appropriately placed at higher hierarchical levels. EUNIS currently fails to provide as much detail for deep-water habitats $(>200 \mathrm{~m})$ as it does for shallow-water habitats (Galparsoro et al. 2012; Tempera et al. 2013).

\subsection{Deep-sea environments}

The first effort to describe seabed assemblages for use in the mapping of the broad deep-sea areas off the European shores is traditionally attributed to Le Danois (1948), who worked on the basis of dredged samples in the Bay of Biscay. More recently, with the dissemination of in situ still and video imagery as a method of sampling the benthos, descriptions of deep-sea benthic assemblages have advanced more rapidly (e.g. Laubier and Monniot 1985; Howell et al. 2010; Vertino et al. 2010, Tempera et al. 2013; Davies et al. 2014, 2015; De Leo et al. 2014). However, these efforts are still restricted to smaller areas within national waters and a comprehensive biogeographical coverage remains to be completed.

This paper contributes to refining existing classification schemes by hierarchically organising the diversity of CWC biotopes inventoried under project CoralFISH using seafloor imagery from the Northeast Atlantic and Mediterranean.

\section{Methods}

\subsection{CoralFISH project}

The CoralFISH project ran between 2008 and 2013 by a consortium of 17 institutes and small/medium enterprises from 11 countries receiving co-funding from the $7^{\text {th }}$ Framework Programme. Its objective was to assess the interaction between CWCs, fish and fisheries in order to develop monitoring and predictive modelling tools for ecosystem-based management in the deep waters of Europe and beyond.

In its scope, six target areas spread out over the Northeast Atlantic Ocean and the Mediterranean Sea were studied: Northern Norway - eastern Norwegian Sea, Iceland, Porcupine Seabight / Rockall Trough, Bay of Biscay, Azores and the Ionian sector of the Mediterranean Sea. 


\section{ACCEPTED MANUSCRIPT}

Figure 1. Schematic representation of the six regional study areas of the CoralFISH project; their location is here referred to the corresponding European marine ecoregion, as defined from the Report of the ICES Advisory Committee on Fishery Management and Advisory Committee on the Ecosystem, 2004. The six study areas are located; (1) offshore south Iceland (ecoregion A); (2) offshore Norway (ecoregion D); (3) offshore western Ireland (Porcupine Bank and Seabight, and Rockall Trough; ecoregion E); (4) offshore western France (Bay of Biscay, ecoregion G); (5) offshore Italy and Greece in the Eastern Mediterranean sea (Northern Ionian sea, ecoregion I) and (6) in the Azores archipelago (ecoregion K).

\subsection{Habitat classification scheme}

\subsubsection{Cold-Water Coral habitat identification}

A CWC habitat was defined where a coherent suite of conspicuous epibenthic organisms including CWCs (as defined by Roberts et al. 2009) extended throughout a minimum estimated area of $25 \mathrm{~m}^{2}$ (as observed by underwater cameras). Generally, the individual habitats catalogued: (i) were repeatedly observed in multiple seafloor photos or along a video footage stretch representing an area $\geq 25 \mathrm{~m}^{2}$ and (ii) showed similar dominant species compositions in different locations. Areas with a high along-track turnover rate in dominant species were interpreted as transitional habitats and avoided in establishing typical species compositions.

The analyses spanned seven major physiographic provinces between 200 and 3,300 m depth, as explained below.

Imagery sources ranged from old discoloured slides from the late 1960's or aged VHS footage from the early 1990's to high-definition (full-HD) video and high-resolution digital photography from the early 2010's with resolutions as high as 3072x2304 pixels (additional details can be found in Vertino et al. 2010; Savini et al. 2014; Rengstorf et al. 2014; Van den Beld et al. this issue; Arnaud-Haond et al. this issue).

\section{Geological classification}

Following Harris et al. (2014) standardised geomorphological classification of the ocean seafloor were used for each level 3 biotope. Within the physiographic provinces investigated by the CoralFISH project, 7 major physiographic provinces were identified: 1 . Continental shelf, 2. Continental slope, 3. Continental rise, 4. Abyssal hills and mountains (seamounts), 5. Volcanic islands (including upper bathyal hill on island slope), 6. Oceanic banks and plateau (Banks rises and plateau), 7. Abyssal plains (basin areas - on abyssal zone). 


\section{ACCEPTED MANUSCRIPT}

In all of the physiographic provinces investigated, CWC were associated with different geomorphic units. The terminology used to define geomorphic units was aimed at indicating (Sensu Harris 2011, which recognises the importance of seafloor geomorphology in understanding the distribution of benthos) the main geomorphic features and substrate types which typify the locations in which CWC biotopes are known from the literature and/or characterised in the six CoralFISH study areas, as described below. Most of the terms used are also reported in standardised classification of ocean basins (although no official agreement exist between scientists in using the most appropriate terms for the different situations - MIM partnership, in press; Dove et al. 2016), for example the ones reported by the International Hydrographic Organisation (IHO, 2008) or by Harris et al. 2014 (Geomorphology of the oceans). Geomorphic units used in our work include Carbonate mounds, Canyon systems, Mass-movement deposits and Submarine glacial landforms that represent the major submarine landforms characterising the surveyed regions in the six CoralFISH study areas. In addition, Bedrock and escarpments were also considered to refer to those regions dominated by erosive processes or hard substrate or mixed sediments (including volcanic substrates forming volcanic cones or other volcanic landforms); whereas those region of the bathyal plane that do not belong to common submarine landforms and are covered by soft sediment, were indicate as Smooth and featureless slope regions.

\subsubsection{Habitat classification}

The main factors taken into consideration in the habitat classification proposed were:

(i) the dominant species or group of species.

(ii) type of substrate, with the two main categories separating hard substrate (including mixed substrate and consolidated mud) and soft substrate; in particular cases, boulder habitats and vertical walls are also discriminated given the major changes in species and environmental conditions associated with them.

(iii) the presence of coral framework (three-dimensional structure created by in-place scleractinians whose skeletons are in mutual contact and/or merged), with subordinate classes distinguishing alive or completely dead framework, the complexity of the 3D structure and the level of colonisation by other groups;

Some additional CWC habitats known from literature but not necessarily encountered in CoralFISH study areas were included with indication of sources, to provide a fully 


\section{ACCEPTED MANUSCRIPT}

comprehensive classification scheme.

The majority of the terminology used in Table 1 follows the CoralFISH glossary for underwater video analysis of European CWC habitats.

\subsubsection{Taxonomical identification}

Emphasis was given to conspicuous habitat-building organisms and main characteristic species when establishing biotopes and the species composition list. Given the limitations in the resolution provided by many imagery sources, generally only taxa $>10 \mathrm{~cm}$ were identified. Where voucher specimens were not collected, the authors' taxonomical expertise and macroscopic correspondence to specimens in reference collections, or to referenced in situ taxa images, were used to establish the best taxonomic identification (i.e. high level of certainty to a given taxonomic level) of the organisms observed in the imagery. Despite the fact that non-calcified hydrozoans are not traditionally considered as corals, the habitats some of them form (e.g. order Leptothecata) share structural (and possibly functional) similarities with gorgonian gardens. They have thus been included in the definition of corals used in the CoralFISH glossary (Beuck et al. in prep) and the biotopes they structure integrate our classifications scheme.

\subsubsection{Correspondences with others classifications}

Wherever possible, correspondence of habitats to the following were achieved (i) Habitats Directive, (ii) OSPAR list of threatened and/or declining species and habitats, (iii) the EUNIS classification, and (iv) FAO/NEAFC Vulnerable Marine Ecosystems (VMEs) (ICES Advice 2013, Book 1). As the FAO categories for VMEs are limited the NEAFC proposed VMEs were used.

Coral gardens are defined in the scope of the OSPAR Convention as a relatively dense aggregation of colonies or individuals of one or more coral species. Following the CoralFISH glossary (Beuck et al. in prep), coral gardens can also be dominated by frame-building scleractinian species but differ from coral frameworks and reefs because coral skeletons are not in mutual contact and do not form large three-dimensional carbonate structures. Where no established criteria or statistical analyses were provided, assemblages were identified as “potential coral garden”. 


\section{Results}

The CWC habitats were classified into three biotope levels (Table 1): Biotope L1 is characterised by the dominant group of taxa and structure (e.g. reef, framework, rubble) or the dominant group of taxa and substrate typology (soft, mixed, hard); Biotope L2 is characterised by the dominant group of taxa, structure and density measure (e.g. dense or loosely-packed framework), substrate and presence of colonisation by other species and Biotope L3 is characterised by the dominant subgroup of taxa (defined at genus or species level where possible), structure and/or substrate and/or secondary group of taxa (colonisation) and, where relevant, geoform. Biotope level relates to varying levels in taxonomic resolution, with level 1 being a low resolution category and 3 being a higher resolution category. Sixteen level 1 biotopes, 25 level 2 and 81 level 3 categories were identified (See Table 1). For some categories it was unclear if there was a placement for the corresponding categories under the listed habitats, in these instances, it was labelled as unclear (See Suppl Table 1).

The majority of these habitats correspond to habitats listed in directives and conventions: 66 fall under the OSPAR list of priority habitats, 62 under the Habitats directive and 71 fit the VME categories established by NEAFC. All 81 habitats could be classified using the substrate classification level in EUNIS, but only 9 corresponded to existing EUNIS biotopes (See Suppl (Guillamount et al. 2016) for full CWC habitat classification and Suppl Table 1 for comparison with other habitat classification scheme and listed habitats). Note that the CMECS (Coastal and Marine Ecological Classification Standard) system developed by NOAA has been included in the Supple table 1 to allow comparison with the CoralFISH Scheme, and also to illustrate a more comprehensive scheme than the current European models. As it is not a European-based system, it will not be discussed within this paper. For each biotope, associated metadata are given in the CWC catalogue (Suppl), with a full list of the physiographic province and geomorphic unit each biotope is associated with throughout the CoralFISH study area given in the Suppl Table 2.

\section{Discussion}

The large diversity of biotopes identified at different resolution levels demonstrates that not only imagery from recent expeditions but also historical photographic datasets represent 


\section{ACCEPTED MANUSCRIPT}

valuable sources of information for deep-sea bionomy, even in situations where the original purpose of the surveys was not biotope recognition (e.g. geological exploration expeditions from the late 1960's up to the 1990's).

\subsection{Listed habitats}

The various initiatives list only three habitats which relate to those biotopes described in the CoralFISH CWC scheme: cold-water coral reefs (OSPAR, Habitats Directive and VME), coral gardens (OSPAR, Habitats directive and VME), and seapen communities (OSPAR and VMEs). These categories are widely used from an operational point of view (i.e. policy making) to give weight to habitats of conservation concern, and the CoralFISH CWC classification scheme presented here highlights a lack of taxonomic details that are of concern for the effectiveness of these categories. For example, under OSPAR, coral gardens are defined as 'a habitat which has a relatively dense aggregation of individuals or colonies of one or more coral species which can occur on a wide range of soft and hard substrates' (OSPAR 2010). In the context of hard substrate this habitat has been described as being dominated by gorgonian, stylasterid and/or antipatharian corals (ICES 2007) and can develop on exposed bedrock, boulders or cobbles (Roberts et al. 2009). The OSPAR definition of coral gardens is very broad, and the habitat in terms of biodiversity and densities of associated species can vary with region, hydrography, topography, substrate and depth (OSPAR 2010). To adequately protect such habitats, better criteria (including examples of coral garden habitats) are required to allow appropriate assessment and discrimination of the distinct habitat types embedded in this category (Bullimore et al. 2013).

The working definitions of listed habitats are restricted and vague. While some biotopes clearly adhere to those described under listed habitats, e.g. Lophelia pertusa reefs (1.1.1 in the proposed CoralFISH scheme) to 'Biogenic reef' (Annex I, Habitats Directive), 'Lophelia pertusa reefs' (OSPAR), and 'deep-sea L. pertusa reefs' (EUNIS); the placement of many others under these schemes is unclear. For example, when Madrepora oculata is the dominant reef-building coral none of the listed categories provides a good fit. Under the Habitats Directive only L. pertusa is mentioned, OSPAR only acknowledges the species as characteristic of the Lophelia dominated reefs and EUNIS can only be used if we take the unspecific level of 'communities of deep-sea corals'.

\subsection{Classification schemes}

Existing habitat classification schemes are not adequate to support representative protection 


\section{ACCEPTED MANUSCRIPT}

of vulnerable deep-sea biotopes such as those formed by cold-water corals. For example, under EUNIS, 'Bioherms' (large biological structures, formed by e.g. corals or sponges) are not split up despite many authors reporting distinct assemblages associated with different bioherm zones [e.g. mostly live coral on coral mound summit; mostly dead framework and coral rubble on the flanks and surrounding seafloor; as described by Mortensen et al. (1995), Pfannkuche et al. (2004), Wienberg et al. (2008), Roberts et al. (2009), Vertino et al. (2010) Davies et al. (2015)]. Additionally, in the EUNIS deep-sea bioherm section (A6.6) only one coral biotope is considered: Deep-sea Lophelia pertusa reefs. This does not reflect the range of deep-sea CWC bioherm biotopes identified by the CoralFISH inventory.

An objective, comprehensive and representative classification scheme using consistent terminology is required for describing the diversity of such habitats found across European seas. The CoralFISH CWC biotope classification scheme (i) addresses the shortcomings of other schemes, (ii) represents the regional variation of cold-water coral habitats and (iii) can be related to habitats listed in EU Directives and international Conventions.

The CoralFISH CWC classification scheme is compatible and could be included with CWC biotopes discrimination at EUNIS levels 4 to 6 - a proposal that is consistent with the perspective of the upcoming EUNIS revision (Doug Evans, unpublished data). It is assumed that at EUNIS level 3 deep-sea habitats are divided on the basis of substrate, which has been endorsed as a valid factor for deep-sea habitat classification (Howell 2010).

In addition, unlike other classification schemes, the CoralFISH CWC classification subdivides scleractinian bioherms into live/dead reef, live/dead coral framework and rubble zones (sensu Mortensen et al. 1995) - an important feature given that these zones are known to vary in associated biodiversity (e.g. Jensen and Frederiksen 1992; Mortensen et al. 1995; Freiwald et al. 2002, Rosso et al. 2010, Spezzaferri et al. 2013). The reef-building coral species are also distinguished, providing a better discrimination of these biotopes than OSPAR, which only accounts for Lophelia pertusa reefs and neglect other dominant species, for example the widely distributed Madrepora oculata (Arnaud-Haond et al. this issue) that is the dominant frame-building species in the Mediterranean (Vertino et al. 2014 and reference therein). This is important from a conservation point of view and promotes the integration of improved representativeness into MPA networks.

\subsection{Data resolution}

Due to technical constraints and the high cost associated with deep-sea research, it is not 


\section{ACCEPTED MANUSCRIPT}

feasible to collect full-coverage biological data (Diaz et al. 2004). For instance, approaches used for mapping shallow-water habitats based on satellite imagery are not applicable to the deep sea. Instead, the vast inaccessible area involved requires broad-scale sub-sampling and modelling accompanied by nested fine-scale surveys.

The methods used to acquire data determine the taxonomic resolution that may be achieved by subsequent analyses. The proposed hierarchical scheme allows data of varying resolutions to be represented. Given that resolutions of imagery datasets being interpreted vary greatly between equipment type, the CoralFISH scheme allows results to be recorded from broad cold-water coral categories down to finer detailed biotope level, thereby providing a flexible yet valuable information level for management.

The CWC habitat classification scheme provides much needed habitat descriptions which ought to be included into existing schemes such as EUNIS. At a nature conservation level, the results are instrumental to identify biotope occurrences that require protection under the Habitats Directive (reefs) and the OSPAR Convention (coral gardens, scleractinian reefs, seapens and burrowing megafauna communities, deep-sea sponge aggregations).

It should be noted that statistical methods (e.g. multivariate cluster analysis) were not employed to describe all level 3 biotopes. Undertaking a fully-quantitative analysis of deepsea data is still very time-consuming due to the faunal complexity of many deep-sea habitats. Frequently it is also taxonomically-limited, as living specimens morphology is poorly documented for many species, which makes their visual identification difficult.

As the datasets explored during CoralFISH were broad and varied, such methods were not feasible for the entire dataset. Analytical methods may aggregate data at a resolution that is not ecological significant, i.e. too small a unit, thus employing a non statistical approach allows expert judgement to be employed. Despite this, the hierarchical system which has been put into place still allows the inclusion of subsequently-defined biotopes when robust quantitative data and statistical analysis are available.

Finally, it must be emphasised that a detailed description of epibenthic assemblages requires further dedicated collections of voucher specimens and continued taxonomy research, preferably including molecular barcoding, on multiple animal groups which remain either unknown to science or visually irresolvable. Besides identification of organisms forming biotopes, further exploration of the deep-sea will potentially reveal biotopes not listed in the CoralFISH classification scheme, since the majority of the deep-seafloor still remains 


\section{ACCEPTED MANUSCRIPT}

unexplored.

\section{Conclusion}

The analyses of a wide variety of imagery datasets from the Northeast Atlantic and Mediterranean within the project CoralFISH showed that the range of cold-water coral (CWC) biotopes is currently very poorly represented in the EUNIS classification system.

In order to address this, a new comprehensive hierarchical scheme is proposed incorporating this additional detail so that it can be readily embedded into the existing deep-sea EUNIS level 4-6. The proposed hierarchy is flexible in accommodating habitat data with different taxonomic resolutions, allowing occurrences from broad $\mathrm{CWC}$ biotope classes down to detailed taxonomy-based categories. This more detailed description and classification of CWC biotopes will facilitate the identification of biotope occurrences requiring protection under the Habitats Directive (reefs) and the OSPAR Convention (coral gardens, scleractinian reefs, seapens and burrowing megafauna communities). The proposed classification scheme will also aid environmental economists engaged in the mapping and assessment of ecosystem goods and services (cf. MAES, 2014).

\section{Acknowledgments}

The authors would like to thank the following projects: CoralFISH (EC/FP7:ENV/2007/1/213144), MeshAtlantic (Atlantic Area 2009-1/110), CORAZON (FCT/PTDC/MAR/72169/2006), HERMIONE (EC/FP7-226354) and DEEPFUN (PTDC/MAR/111749/2009). FT also benefited from a 3-month EGIDE scientific fellowship grant (ref. 736169F) for his work at Ifremer-Brest and the Centre d'Océanologie de Marseille. The authors also acknowledge funds provided by FCT-IP/MEC to IMARUniversity of the Azores (R\&D Unit no. 531), LARSyS Associated Laboratory through the Strategic Project PEst-OE/EEI/LA0009/2011-2014 (COMPETE, QREN), EDRF, ESF and the Government of Azores FRCT multiannual funding and RITMARE project to the ULR CoNISMa of Milano-Bicocca University, the COCARDE-ERN (European Science Foundation) project and FIRB-APLABES (Italian Ministry). The work also benefited from the ESF COCARDE network activities. 


\section{References}

92/43/EEC Council Directive 92/43/EEC of 21 May 1992 on the conservation of natural habitats and of wild fauna and flora. OJ L206, 22.07.92. p.7.

Arnaud-Haond, S., Van Den Beld, I., Becheler, R., et al., this issue. Two "pillars" of coldwater coral reefs along Atlantic European margins: Prevalent association of Madrepora oculata with Lophelia pertusa, from reef to colony scale. Deep Sea Res Part II: Topical Studies in Oceanography http://dx.doi.org/10.1016/j.dsr2.2015.07.013.

Cartes, J., LoIacono, E.C., Mamouridis, V., et al., 2013. Geomorphological, trophic and human influences on the bamboo coral Isidella elongata assemblages in the deep Mediterranean: To what extent does Isidella form habitat for fish and invertebrates? Deep Sea Res. I 76:52-65.

Auster, P.J., Moore, P., Heinonen, K et al., 2005. A habitat classification scheme for seamount landscapes: assessing the functional role of deepwater corals as fish habitat. p. 761-769. in: A. Freiwald and J.M. Roberts (eds.) Cold-water Corals and Ecosystems, Springer-Verlag, Berlin Heidelberg).

Beuck, L., Vertino, A.V., Savini, A., et al., in prep. Towards a standardised habitat characterisation of deep-water coral ecosystems.

Bryan, T.L., Metaxas, A., 2007. Predicting suitable habitat for deep-water gorgonian corals on the Atlantic and Pacific Continental Margins of North America. Marine Ecology Progress Series 330: 113-126.

Bullimore R., Foster N., Howell K, 2013. Coral-characterized benthic assemblages of the deep Northeast Atlantic: defining "Coral Gardens" to support future habitat mapping efforts. ICES Journal of Marine Science 70:511-522.

Dahl, F., 1908. Grundsaetze und grundbegriffe der biocoenotischen forshung. Zoologische Anzeiger 33: 349-353. 


\section{ACCEPTED MANUSCRIPT}

Davies, J.S., Howell, K.L., Stewart, H.A., et al., 2014. Defining biological assemblages (biotopes) of conservation interest in the submarine canyons of the South West Approaches (offshore United Kingdom) for use in marine habitat mapping. Deep Sea Res II. http://dx.doi.org/10.1016/j.dsr2.2014.02.001.

Davies, J.S., Stewart, H.A., Narayanaswamy, B.E., et al., 2015. Benthic assemblages of the Anton Dohrn Seamount (NE Atlantic): defining deep-sea biotopes to support habitat mapping and management efforts with a focus on Vulnerable Marine Ecosystems. PLos ONE. http://dx.doi.org/10.1371/journal.pone.0124815.

De Leo F.C., Smith, C.R., Vetter, E.W., et al., 2014. Spatial scale-dependent habitat heterogeneity influences submarine canyon macrofaunal abundance and diversity off the Main and Northwest Hawaiian Islands. Deep-Sea Res II 104: 267-290.

De Mol, B., Van Rensbergen, P., Pillen, S., et al., 2002. Large deep-water coral banks in the Porcupine Basin, southwest of Ireland. Marine Geology 188: 193-231.

Diaz, R.J., Solan, M., Valente, R.M., 2004. A review of approaches for classifying benthic habitats and evaluating habitat quality. Journal of Environmental Management 73(3): 165181.

Dove, D., Bradwell, T., Carter, G., et al. 2016. Seabed Geomorphology: a twopart classification system. MARINE Geoscience PROGRAMME OPEN REPORT OR/16/001. Brithis Geological Survey.

FAO, 2009. International Guidelines for the Management of Deep-sea Fisheries in the High Seas. Rome.

Fosså, J.H., Mortensen, P.B., Furevik, D.M., 2002. The deep-water coral Lophelia pertusa in Norwegian waters: distribution and fishery impacts. Hydrobiologia 471, 1-12.

Frederiksen, R., Jensen, A., Westerberg, H., 1992. The distribution of the scleractinian coral Lophelia pertusa around the Faroe Islands and the relation to internal mixing. Sarsia 77: 157171. 
Freiwald, A., Wilson, J.B., Henrich, R., 1999. Grounding Pleistocene icebergs shape recent deep-water coral reefs. Sediment Geology 125: 1-8. 2002: Reef-forming cold-water corals. Ocean Margin Systems. G. Wefer, Billett, D., Hebbeln, D., Jørgensen, B.B., Schlüter, M. and van Weering, T.C.E. Heidelberg, Springer: 365-385.

Freiwald, A., Beuck, L., Ruggeberg, A. et al., 2009. The white coral community in the central Mediterranean Sea revealed by ROV surveys. Oceanography 22: 58-74.

Freiwald, A., Fosså, J.H., Grehan, A., et al., 2004. Cold-water Coral Reefs. UNEP-WCMC. Cambridge, UK.

Galparsoro, I., Connor, D.W., Borja, Á., et al., 2012. Using EUNIS habitat classification for benthic mapping in European seas: present concerns and future needs. Marine Pollution Bulletin, 64(12), 2630-2638.

Genin, A., Dayton, P.K., Lonsdale, P.F. et al., 1986. Corals on seamount peaks provide evidence of current acceleration over deep-sea topography. Nature 322: 59-61.

Gori, A., Orejas, C., Madurell, T., et al., 2013. Bathymetrical distribution and size structure of cold-water coral populations in the Cap de Creus and Lacaze-Duthiers canyons (northwestern Mediterranean). Biogeosciences 10, 2049

Greene, H.G., Yoklavich, M.M., Starr, R.M., et al., 1999. A classification scheme for deep seafloor habitats. Oceanologica Acta 22(6): 663-678.

Grehan, A.J., Unnithan, V., Olu, K., et al., 2005. Fishing impacts on Irish deep-water coral reefs: making a case for coral conservation. Am. Fish. Soc. Symp. 41, 819-832.

Guillaumont, B., Davies, J.S., Tempera, F. et al., 2016. CoralFISH Northeast Atlantic and Mediterranean Cold-Water Coral Habitats Catalogue (Version 2).

Henry, L.A., Roberts, J.M., 2007. Biodiversity and ecological composition of macrobenthos on cold-water coral mounds and adjacent off-mound habitat in the bathyal Porcupine 


\section{ACCEPTED MANUSCRIPT}

Seabight, NE Atlantic. Deep-Sea Research II 54(4): 654-672.

Howell, K.L., 2010. A benthic classification system to aid in the implementation of marine protected area networks in the deep/high seas of the NE Atlantic. Biological Conservation 143: 1041-1056.

Howell, K.L., Davies, J.S., Narayanaswamy, B.E., 2010. Identifying deep-sea megafaunal epibenthic assemblages for use in habitat mapping and marine protected area network design. Journal of the Marine Biological Association of the United Kingdom 90(1): 33-68.

ICES., 2007. Report of the Working Group on Deep-Water Ecology (WGDEC), 10-14 March 2008. ICES Journal of Marine Science: 1-122.

ICES Advice 2013, Book 1. General advice Assessment of the list of VME indicator species and elements.

Jensen, A., Frederiksen, R., 1992. The fauna associated with the bank-forming deepwater coral Lophelia pertusa (Scleractinaria) on the Faroe shelf. Sarsia 77: 53-69.

Laubier, I., Monniot, C., 1985. Les peuplements du golfe de Gascogne, Campagnes BIOGAS. Brest: Ifremer: pp 630.

Le Danois, E., 1948. Les profondeurs de la mer, trente ans de recherches sur la faune sousmarine au large des côtes de France. Payot, Paris: pp 303.

Lo Iacono, C., Victorero Gonzalez, L., Huvenne, V., et al., 2014. Morphology and shallow stratigraphy of the West Melilla and Cabliers CWC Mounds (Alborán Sea). Preliminary insights from the GATEWAYS MD194 Cruise. In Van Rooij D. and Rüggeberg A. (Eds). 2014. Book of Abstracts. 2nd Deep-Water Circulation Congress: The Contourite Log-book. Ghent, Belgium, 10-12 September 2014. VLIZ Special Publication 69: 115-116.

MacIsaac, K., Bourbonnais, C., JKenchington, E., et al., 2001. Observations on the occurrence and habitat preference of corals in Atlantic Canada. In: Willison JHM, Hall J, Gass SE, Kenchington ELR, Butler M, Doherty $\mathrm{P}$ (Eds). Proceedings of the First 


\section{ACCEPTED MANUSCRIPT}

International Symposium on Deep-Sea Corals, 30 July-3 August 2000. Ecology Action Center and the Nova Scotia Museum, Halifax: pp 58-75.

MAES., 2014. Mapping and Assessment of Ecosystems and their Services Indicators for ecosystem assessments under Action 5 of the EU Biodiversity Strategy to 2020, 2nd Report Final, February 2014, European Commission Technical Report - 2014 - 080.

Mastrototaro, F., Maiorano, P., Vertino, A., et al., 2013. A Kophobelemnon (Cnidaria, Octocorallia) facies from Santa Maria di Leuca coral province (Mediterranean Sea). Marine Ecology, 34(3), 313-320.

Mastrototaro, F., D’Onghia, G., Corriero, G., et al. 2010. Biodiversity of the white coral bank off Cape Santa Maria di Leuca (Mediterranean Sea): An update. Deep-Sea Res Part II: Topical Studies in Oceanography 57:412-430. doi:10.1016/j.dsr2.2009.08.021.

MIM partnership (MAREANO, INFOMAR, MAREMAP), in press. National programmes: Geomorphological mapping at multiple scales for multiple purposes. In: Micallef A., Krastel S., Savini A. (Eds.). Submarine Geomorphology, in press. Springer.

Mortensen, P.B., Hovland, M., Brattegard, T., et al., 1995. Deep water bioherms of the scleractinian coral Lophelia pertusa (L.) at $64^{\circ} \mathrm{N}$ on the Norwegian shelf: structure and associated megafauna. Sarsia 80: 145-158.

O'Hara, T.D., Rowden, A.A., Williams, A., 2008. Cold-water coral habitats on seamounts: do they have a specialist fauna? Diversity and Distribution 14: 925-934.

OSPAR (Agreement 2008-6). OSPAR Agreement 2008-6 that replaced an earlier version of the list contained in OSPAR Agreement 2004-6 (see also the Summary Record of the 2008 meeting of the OSPAR Commission contained in OSPAR 08/24/1, Para. 7.12).

OSPAR., 2010. Background Document for Coral Gardens. Biodiversity Series: pp 38.

Pfannkuche, O., Bannert, B., Beck, T., et al., 2004. Geo-Biological Investigations on Azooxanthellate Cold-Water Coral Reefs on the Carbonate Mounds along the Celtic 


\section{ACCEPTED MANUSCRIPT}

Continental Slope. L. A. t. M. Meteror Cruise No. 61, 2004, Lisbon - Cork.

Rengstorf, A.M., C. Mohn, C., Brown, M.S., et al., 2014. Predicting the distribution of deepsea vulnerable marine ecosystems using high-resolution data: Considerations and novel approaches, Deep Sea Res Part I: Oceanographic Research Papers, 93: 72-82.

Roberts 2002. Deep impact: the rising toll of fishing in the deep sea. Trends in ecology \& evolution 17(5): 242-245.

Roberts, J.M., Wheeler, A.L., Freiwald, A. et al., 2009. Cold-water corals. The biology and Geology of Deep-Sea Coral Habitats. New York.

Roberts, K., Jones, D.O.B., Tyler, P.A., et al., 2014. Finding the hotspots within a biodiversity hotspot: fine-scale biological predictions within a submarine canyon using highresolution acoustic mapping techniques. Marine Ecology 36(4): 1256-1276. DOI: $10.1111 /$ maec.12228.

Rogers, A.D., 1999. The biology of Lophelia pertusa (Linnaeus, 1758) and other deep-water reef-forming corals and impacts from human activities. Int. Rev. Hydrobiol. 84, 315-406.

Rosso, A., Vertino, A., Di Geronimo, I., et al., 2010. Hard versus soft-bottom thanatofacies from the Santa Maria di Leuca deep-water coral mound province, Recent Mediterranean. Deep-Sea Research II 57 (5-6): 360-379.

Sanfilippo, R., Vertino, A., Rosso, A., et al., 2012. Serpula aggregates and their role in deepsea coral communities in the southern Adriatic. Facies 59: 663-677.

Savini, A., Corselli, C., 2010. High resolution bathymetry and acoustic geophysical data from Santa Maria di Leuca cold water coral province (northern Ionian Sea-Apulian continental slope). Deep-Sea Res II 57 (5-6): 326-344.

Savini, A., Vertino, A., Marchese, F., et al., 2014. Mapping cold- water coral habitats at different scales within the northern Ionian Sea (central Mediterranean): an assessment of coral coverage and associated vulnerability. PloS One9 (1), e87108. 


\section{ACCEPTED MANUSCRIPT}

http://dx.doi.org/10.1371/journal.pone.0087108.

Savini, A., Marchese, F., Verdicchio, G., et al., 2016. Submarine Slide Topography and the Distribution of Vulnerable Marine Ecosystems: A Case Study in the Ionian Sea (Eastern Mediterranean). In: G. Lamarche et al. (eds.), Submarine Mass Movements and Their Consequences. Springer, Heidelberg, 163-170

Spezzaferri, S., Rüggeberg, A., Stalder, C., et al., 2013. Benthic foraminifera from Norwegian cold-water coral reefs. Journal of Foraminiferal Research, 43:1, 21-39.

Taviani, M., Vertino, A., López Correa, M., et al., 2011. Pleistocene to Recent scleractinian deep-water corals and coral facies in the Eastern Mediterranean. Facies 57:579-603.

Taviani, M., Angeletti, L., Canese, S., et al., 2015. The "Sardinian cold-water coral province" in the context of the Mediterranean coral ecosystems. Deep Sea Res. Part II, doi:10.1016/j.dsr2.2015.12.008

Tempera, F., Atchoi, E., Amorim, P., et al., 2013. Atlantic Area Marine Habitats. Adding new Macaronesian habitat types from the Azores to the EUNIS Habitat Classification. MeshAtlantic Technical Report, 4/2013. IMAR/DOP-UAç, Horta, 126pp. http://www.meshatlantic.eu/assets/files/bluebox/02b_Azores_Marine_Habitats\%20v1_1.pdf.

Tempera, F., Carreiro-Silva, M., Jakobsen, K. et al., 2015. Mar Biodiv 45:3-4 doi:10.1007/s12526-014-0220-9.

Tunesi, L., Diviacco, G., Mo, G., 2001. Observations by submersible on the biocoenosis of the deep-sea corals off Portofino promontory (Northwestern Mediterranean Sea). In: Proceedings of the First International Symposium on DeepSea Corals. J.H.M. Willison, J.Hall, S. Gass, E.L.R. Kenchington, M. Butler, and P. Doherty, eds, Ecology Action Centre and Nova Scotia Museum, Halifax, 76-87.

UNGA., 2006. Resolution 61/105 Sustainable fisheries, including through the 1995 Agreement for the Implementation of the Provisions of the United Nations Convention on the Law of the Sea of 10 December 1982 relating to the Conservation and Management of 


\section{ACCEPTED MANUSCRIPT}

Straddling Fish Stocks and Highly Migratory Fish Stocks, and related instruments. UNGA A/RES/61/105.

Van den Beld, I.M.J., Bourillet, J-F., Arnaud-Haond, S., et al. In press. Cold-water coral habitats in submarine canyons of the Bay of Biscay. Frontiers in Marine Science, section Deep-Sea Environnements and Ecology.

Van den Beld, I.M.J., Guillaumont, B., Menot, L., this issue. Marine litter in submarine canyons of the Bay of Biscay. Deep Sea Res Part II: Topical Studies in Oceanography. http://doi.org/10.1016/j.dsr2.2016.04.013.

Vertino, A., Savini, A., Rosso, A., et al., 2010. Benthic habitat characterization and distribution from two representative sites of the deep-water SML coral mound province (Mediterranean). Deep-Sea Res. II 57, 380-396.

Vertino, A., Stolarski, J., Taviani, M., et al., 2014. Mediterranean Corals: from Miocene to Recent. In Goffredo S, Dubinsky Z (eds.): The Mediterranean Sea: Its History and Present Challenges. Springer, 257-74.

Waller, R., Watling, L., Auster. P., et al., 2007. Anthropogenic impacts on the Corner Rise Seamounts, NW Atlantic Ocean. Journal of the Marine Biological Association of the United Kingdom 87:1075-1076.

Wienberg, C., Beuck, L., Heidkamp, S., et al., 2008. Franken Mound: facies and biocoenoses on a newly-discovered "carbonate mound" on the western Rockall Bank, NE Atlantic. Facies 54: $1-24$.

Wienberg, C., Hebbeln, D., Fink, H.G., et al., 2009. Scleractinian cold-water corals in the Gulf of Cádiz-First clues about their spatial and temporal distribution. Deep Sea Research Part I: Oceanographic Research Papers 56(10), 1873-1893. doi: http://dx.doi.org/10.1016/j.dsr.2009.05.016. 


\section{ACCEPTED MANUSCRIPT}

Table 1: CoralFISH cold-water coral biotope classification scheme. The hierarchical scheme is set over three levels: biotope L1 incorporates dominant group of taxa and structure or the dominant group of taxa and substrate, biotope L2 incorporates dominant group of taxa, structure, density measures, substrate, and biotope L3 includes dominant subgroup of taxa, structures and/or substrate and/or secondary taxa groups and where relevant, geoform.

\begin{tabular}{|c|c|c|c|}
\hline $\begin{array}{l}\text { BIOTOPE - } \\
\text { LEVEL } 1 \\
\text { (dominant group } \\
\text { of taxa, structure } \\
\text { and/or substrate) }\end{array}$ & $\begin{array}{c}\text { BIOTOPE - } \\
\text { LEVEL } 2 \\
\text { (dominant group } \\
\text { of taxa, structure, } \\
\text { density and/or } \\
\text { substrate) } \\
\end{array}$ & $\begin{array}{c}\text { BIOTOPE - LEVEL } 3 \\
\text { (dominant subgroup of taxa, structure } \\
\text { and/or substrate and/or secondary } \\
\text { taxa, geoform) }\end{array}$ & FINAL CODE \\
\hline \multirow{13}{*}{$\begin{array}{l}\text { 1. CW Scleractinian } \\
\text { Reef }\end{array}$} & \multirow{6}{*}{$\begin{array}{l}\text { 1. CW } \\
\text { Scleractinian Reef }\end{array}$} & 1. Lophelia pertusa Reef & 1.1 .1 \\
\hline & & 2. Madrepora oculata Reef & 1.1 .2 \\
\hline & & $\begin{array}{l}\text { 3. Mixed Madrepora oculata and } \\
\text { Lophelia pertusa Reef }\end{array}$ & 1.1 .3 \\
\hline & & $\begin{array}{l}\text { 4. Lophelia pertusa and/or Madrepora } \\
\text { oculata Reef with dense Aphrocallistes }\end{array}$ & 1.1 .4 \\
\hline & & $\begin{array}{l}\text { 5. Lophelia pertusa and/or Madrepora } \\
\text { oculata } \text { Reef with dense free swimming }\end{array}$ & 1.1.5 \\
\hline & & Crinoids & \\
\hline & 2. Colonised CW & $\begin{array}{l}\text { 1. Lophelia pertusa Reef Colonised by } \\
\text { Primnoa } \mathrm{sp} \text {. and Plexauridae }\end{array}$ & 1.2 .1 \\
\hline & Scleractinian Reef & $\begin{array}{l}\text { 2. CW Scleractinian Reef Colonised by } \\
\text { Antipatharians and/or Gorgonians }\end{array}$ & 1.2 .2 \\
\hline & $\begin{array}{l}\text { 3. Loosely-packed } \\
\text { CW Scleractinian } \\
\text { Framework with } \\
\text { Soft Substrate }\end{array}$ & $\begin{array}{l}\text { 1. Loosely-packed Lophelia pertusa } \\
\text { and/or Madrepora oculata Framework } \\
\text { with Soft Substrate }\end{array}$ & 1.3 .1 \\
\hline & & $\begin{array}{l}\text { 1. Loosely-packed Lophelia pertusa } \\
\text { Framework Colonised by Primnoa sp. } \\
\text { and Plexauridae }\end{array}$ & 1.4 .1 \\
\hline & $\begin{array}{l}\text { Loosely-packed } \\
\text { CW Scleractinian } \\
\text { Framework with } \\
\text { Soft Substrate }\end{array}$ & $\begin{array}{l}\text { 2. Loosely-packed Lophelia pertusa } \\
\text { and/or Madrepora oculata Framework } \\
\text { with Soft Substrate Colonised by } \\
\text { Antipatharians }\end{array}$ & 1.4 .2 \\
\hline & & $\begin{array}{l}\text { 3. Loosely-packed Solenosmilia } \\
\text { variabilis Framework with Soft Substrate } \\
\text { Colonised by Gorgonians }\end{array}$ & 1.4 .3 \\
\hline & $\begin{array}{l}\text { 5. Predominantly } \\
\text { dead CW } \\
\text { Scleractinian Reef }\end{array}$ & $\begin{array}{l}\text { 1. Isolated Madrepora oculata-Lophelia } \\
\text { pertusa colonies on } \\
\text { Framestones/Rudstones } \\
\text { 2. Isolated Madrepora oculata-Lophelia } \\
\text { pertusa colonies on predominantly dead } \\
\text { and low coral framework }\end{array}$ & 1.5 .1 \\
\hline
\end{tabular}


6. Dead CW

Scleractinian Reef
1. Dead Lophelia pertusa and/or

Madrepora oculata Framework with

Brisingids
1.6 .1

2

2. CW Scleractinian

Rubble

3. Colonial CW

1. Densely-packed

Scleractinians or

CW Scleractinian 1. Dense Lophelia pertusa Framework on

Stylasterids on Hard Framework on

Vertical Wall

Substrate

Hard Substrate

2. Dense Solenosmilia variabilis

Framework on Vertical Wall

3. Dense Eguchipsammia Framework on Hard Substrate

2. Colonised CW

Scleractinian

1. Solenosmilia variabilis Framework on

Framework on

Vertical Wall Colonised by Gorgonians

Hard Substrate

2. Solenosmilia variabilis Framework on Vertical Wall Colonised by Ascidians

3. Loosely-packed to Isolated colonies of CW

1. Isolated Colonies of Lophelia pertusa on Hard Substrate

Scleractinians on

Hard Substrate

2. Isolated Colonies of Madrepora oculata on Hard Substrate (Vertical wall)

3. Isolated Colonies of Madrepora

oculata and Lophelia pertusa on Hard

Substrate

4. Isolated Colonies of Madrepora oculata and Lophelia pertusa on Hard

Substrate with Euplectellidae

5. Isolated Scleractinians Colonies on

Boulders

6. Dendrophyllia cornigera on Hard

Substrate/Mixed Substrate

7. Enallopsammia rostrata on Hard

Substrate

4. CW Stylasterids 1. Errina dabneyi and Sponges on on Hard Substrate Exposed Rocky Edges

5. Dead CW

Scleractinian

Framework on

2. Crypthelia sp. on Hard Substrate

1. Dead Madrepora oculata-Lophelia pertusa Framework on Hard Substrate

Hard Substrate 


\begin{tabular}{ll}
\hline & 1. Solitary CW \\
4. Solitary CW & Scleractinians on \\
Scleractinians on & Hard/Mixed \\
Hard Substrate & $\begin{array}{l}\text { Substrate or } \\
\text { Compact Mud }\end{array}$
\end{tabular}

1. CW Alcyoniina

5. CW Alcyoniina on Hard substrate

6. $\mathrm{CW}$

Antipatharians and/or Gorgonians on Hard Substrate on Hard/Mixed

Substrate or

Compact Mud

\section{CW}

Antipatharians on

Hard/Mixed

Substrate or

Compact Mud
1. Vaughanella sp. on Hard Substrate

Covered by Soft Substrate

2. Solitary caryophyllids on Mixed

Substrate

1. Anthomastus sp. on Hard/Mixed

Substrate or Compact Mud

2. Nephtheidae on Hard/Mixed Substrate or Compact Mud

1. Antipatharians on Hard Substrate

2. Antipathes dichotoma on Hard

Substrate with intense sedimentation

3. Leiopathes glaberrima on Boulders

2. CW Gorgonians on Hard/Mixed Substrate or 1. Iridogorgia sp. and other Gorgonians on Hard/Mixed Substrate Compact Mud

2. Chrysogorgia sp. and Acanella sp. on Hard Substrate

3. Viminella flagellum on Hard/Mixed Substrate

4. Viminella sp. and Dentomuricea sp. on Hard/Mixed Substrate

5. Isidella elongata on Hard/Mixed

Substrate or Compact Mud

6. Narella cf. versluysi on Hard Substrate

7. Primnoa resedaeformis on Hard/Mixed Substrate or Compact Mud

8. Acanthogorgia spp. and Large

Primnoids on Hard/Mixed Substrate

9. Dentomuricea sp. on Mixed Substrate

10. Swiftia pallida on Hard/Mixed

Substrate or Compact Mud

11. Plexauridae spp. on Hard/Mixed Substrate

12. Paragorgia arborea on Hard/Mixed

Substrate 


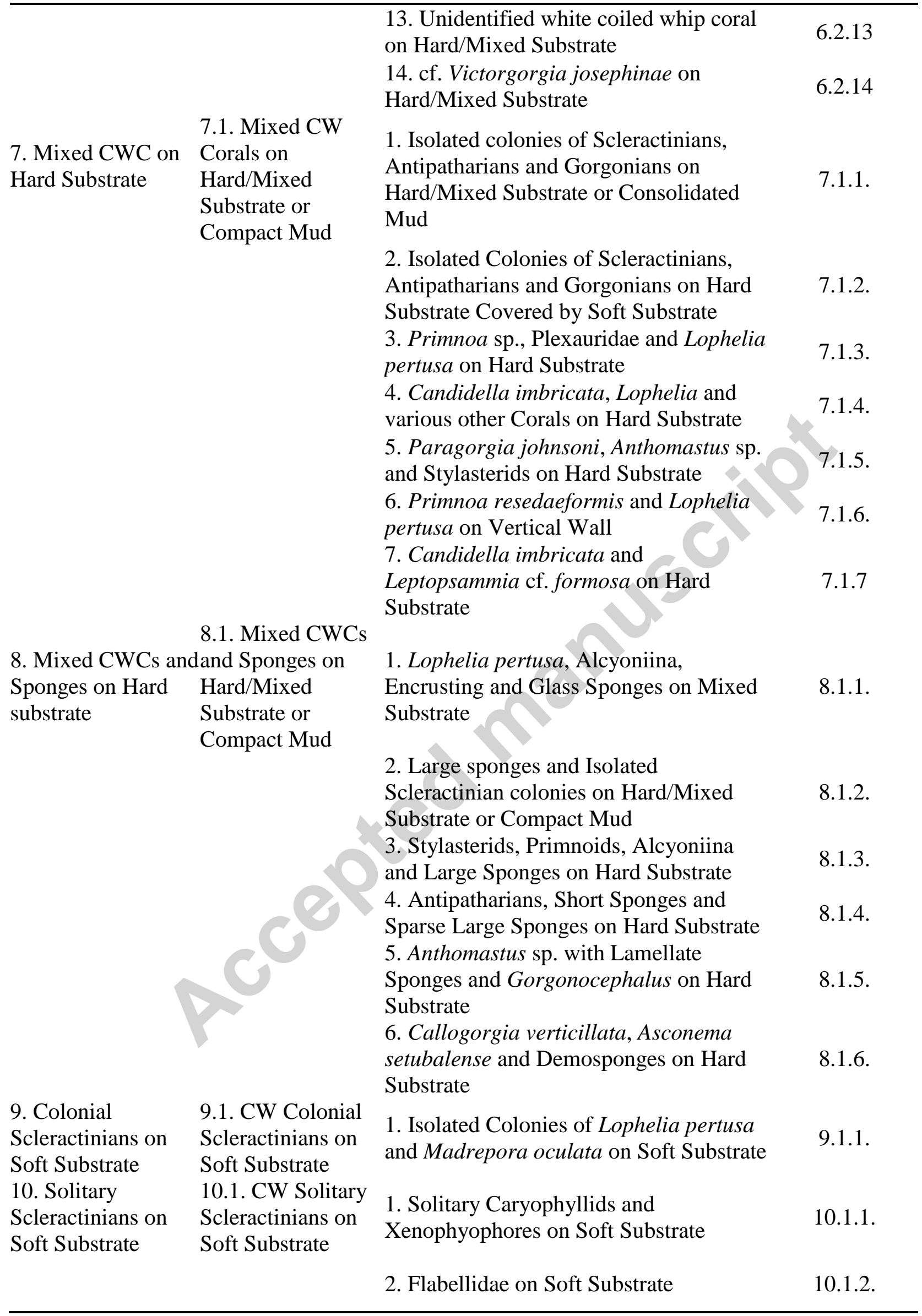


11. Gorgonians on Soft Substrate
11.1. CW

Gorgonians on Soft 1. Radicipes sp. on Soft Substrate

Substrate

2. Callogorgia verticillata on Soft

Substrate

3. Acanella sp. on Soft Substrate

11.1.3

4. Acanella arbuscula and Lepidisis sp. on Soft Substrate

5. Acanella arbuscula and Unidentified

Branched Coral on Soft Substrate

11.1.1.

11.1.2

11.1.5.
11.1.4.

12.1.1. on Soft Substrate Substrate

$\begin{array}{ll}\text { on Soft Substrate } & \text { on Soft Substrate } \\ \text { 13. Mixed CWCs } & \text { 13.1. Mixed CW }\end{array}$ 13. Mixed CWCs 13.1. Mixed CW and Sponges on SoftCorals and Sponges 1. Acanella arbuscula and Hyalonema spp. on Soft Substrate

14. CW Seapens on 14.1. CW Seapens 1. Funiculina quadrangularis and Soft Substrate on Soft Substrate

Burrowing Megafauna on Soft Substrate

2. cf. Halipteris sp. on Soft Substrate

3. Kophobelemnon stelliferum on Soft Substrate

4. Pennatula spp. on Soft Substrate

14.1.4.

5. Distichoptilum gracile on Soft Substrate

15. CW Hydrarians 15.1. CW on Hard/Mixed Hydrarians on

1. Hydrarians (cf. fam. Sertulariidae) on Hard Substrate

Substrate Hard/Mixed Substrate

16. CW Hydrarians on Soft Substrate
Hydrarians on Soft Substrate
1. Lytocarpia myriophyllum on Soft Substrate
16.1.1. 


\section{ACCEPTED MANUSCRIPT}

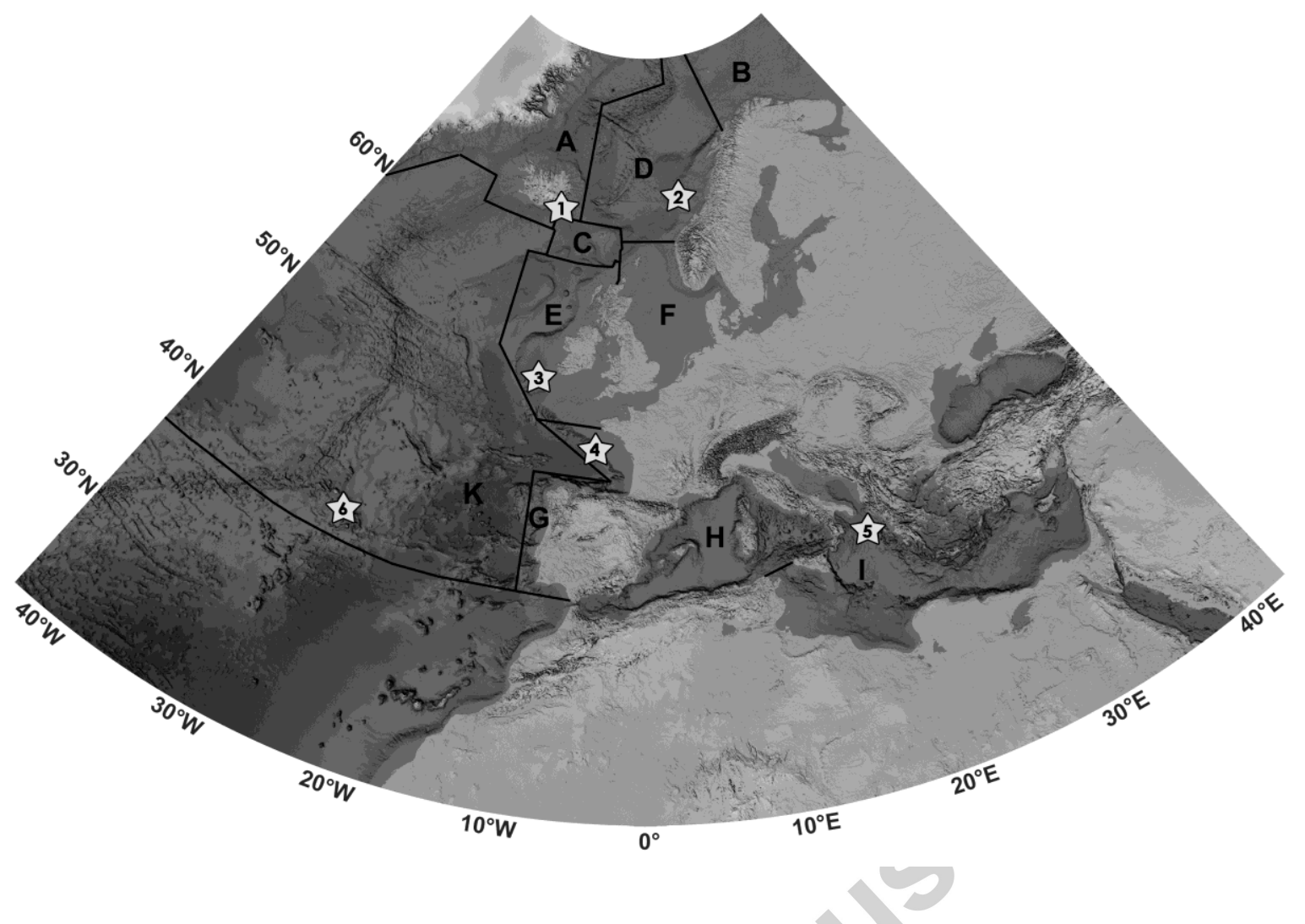

